\title{
The Main Difficulties When Studying Russian Verbs of Motion in a Figurative Meaning
}

\author{
Irina Skripnikova \\ Philological Faculty, Herzen State Pedagogical University of Russia, Saint-Petersburg, Russia \\ Email: skripnik_2209@mail.ru \\ Received September 15 $5^{\text {th }}, 2012$; revised October 16 $6^{\text {th }}, 2012$; accepted October $23^{\text {rd }}, 2012$
}

\begin{abstract}
Russian language acquisition requires deep and intensive studying of the concept of verbs of motion. There is a strong opinion that verbs of motion are one of the hardest concepts in the Russian language. However, it is an important issue, as motion verbs are among the most used in any language and nowadays there are hundreds of expressions with these verbs which can be heard quite frequently in the Russian language. Needless to say that mastering these verbs is even harder when they have figurative meaning. Therefore, the purpose of this paper is to demonstrate the importance of studying the figurative meanings of Russian verbs of motion and to prove that the process of teaching students these verbs is more efficient when they are compared with their English equivalents.
\end{abstract}

Keywords: Verbs of Motion; Figurative Meaning; Russian Language Acquisition; Idiomatic Expression

\section{Introduction}

A verb of motion, as the name suggests, is simply a verb that will take you from one place to another. For example verbs like "go", "walk", "run", "swim" or "fly". So why is it difficult to use them? Russian linguist Konstantin Snejko (2008) in his research "Verbs of motion Идти-ходить (to go), ехать-ездить (to go) and their equivalents in the English language" points out that the acquisition of verbs of motion causes the students to have many difficulties, as these verbs in the Russian language are different from another language students can speak fluently.

Some researchers believe that one of the strongest distinguishing features of Russian verbs of motion is that they exist in pairs. Although the pair of verbs "идти-ходить", “ехать-ездить" belong to different root groups, they point at the same reality. These verbs correspond to the English word "to go" but are able to express opposite meanings like "to drive", "to walk", "to swim", "to fly". Essentially, there is no word in Russian that is like the English "go". Instead Russians always indicate how they are going somewhere.

There is a list of difficulties students or teachers might face when studying verbs of motion:

- English verbs of motion (to go, to arrive, to depart, to come) do not create couples like unidirectional (идти)-multidirectional (ходить), but express themselves in antonymous relations. For instance, the verb "идти" can be translated as "to go" and "to come", which in English language systems are antonyms. This causes extra difficulties for foreign students studying Russian.

- There are two similar Russian words corresponding to every one English verb of motion. This is because Russians indicate whether they are going away from a location or making a return trip. As it is often the case in Russian, you are able to say a lot with few words.

- In English, one verb can express several meanings. However, in the Russian language the meaning and the word itself changes with the use different prepositions. This normally adds a direction to its meaning. For example, you can change the meaning of "walk" to "walk in (the forest)", but in the Russian language you would need to change the whole word as well: “ходить”-“гулять в (лесу)”.

- In Russian there is an interesting phenomenon called the "concretization of motion", but in the English language the relevant equivalents to this phenomenon have a wider meaning-movement in space generally. For instance, the verb "to go" as it was mentioned above corresponds to "идти" ("to go"), “лететь" (“to fly"), "ехать" (“to drive"), “плыть" ("to swim") etc. It can be illustrated with the following:

$\checkmark$ Я иду в школу-I'm going to school;

$\checkmark$ Она едет домой на автобусе- She is going to school by bus.

- In some cases the English verb of motion "to go" cannot translate the meaning of the Russian verbs “идти-ходить”, “ехать-ездить". For instance, while expressing an ability to move in a curtain(Is this the correct word here?) way, the verb "to go" is not able to express the meaning: "Моемy сыну уже восемь месяцев и он уже ходит" (My son is eight months old and he already walks). Quite often foreign students make mistakes with this expression, while translating phrases with a bilingual dictionary. Instead of the verb "to go" this sentence calls for the verb "to walk". This verb does not only express the use of the feet for locomotion. It can also express the ability to move across the floor.

\section{Russian Verbs of Motion That Take Figurative Meanings in Word Combinations}

Traditionally, the figurative meaning of verbs of motion are studied as a part of the general topic "Verbs of motion" and consequently the method of teaching these verbs is exactly the same as the literal meaning of these verbs. However, this approach is not completely effective due to the following reasons.

On the one hand, for native Russian speakers, the figurative meaning of verbs of motion is not equivalent to their literal 
meaning. These verbs and their combinations often function as independent lexical units:

$\checkmark$ Вести войну-To wage a war;

$\checkmark$ Вести дневник-To keep a diary;

$\checkmark$ Подвести кого-нибудь-To trick somebody out.

Moreover, when studying Russian as a foreign language, students might use Russian verbs of motion with a figurative meaning incorrectly because of using the same grammar rules as they would use for verbs of motion with a literal meaning. This could lead to the following mistakes:

$\checkmark$ Осенью у нас часто ходит дождь-Rain often walks here in autumn;

$\checkmark$ Наша фирма водит переговоры с поставщиками-Our organization leads negotiations with a suppliers.

E. I. Kalinovskaya and N. S. Tkachenko have developed a methodical manual which is tailored for those students who are already familiar with basic usage of Russian verbs of motion and are currently studying Russian verbs of motion with a figurative meaning. The concept of verb as a main and basic component of word combination - is a core of this methodical manual. The following quotation sums up the traditional approach when working with these word combinations. "Till now word combinations with verbs are being generated from the verb. This is exactly the way how they are represented in dictionaries and other relevant literature" (Kalinovskaya \& Tkachenko, 1972).

However, in practice when students are learning Russian as a foreign language the most convenient and productive method to generate new word combinations is to be based on the noun (substantive). This approach is more effective than the traditional one for the following reasons:

- Systematization of nouns leads to more accurate and efficient rules for the usage of figurative verbs of motion. For instance, there are certain groups of nouns with ambiguous values, which are productive members of combinations with figurative verbs of motion. When using each of these verbs its meaning is constant, and the choice of noun doesn't influence it. Below are some examples, where nouns with the general meaning "event" are combined with verbs of motion used figuratively in such a way as to change the meaning of the whole sentence:

$\checkmark$ Время идёт-Time goes by;

$\checkmark$ Жизнь идёт-Life goes on;

$\checkmark$ Дождь (снег) идёт-It rains (snows);

$\checkmark$ Идёт урок (лекция)-A lesson (lecture) is in progress;

$\checkmark$ Идёт фильм (спектакль) - A film (play) is on.

- Secondly, the noun carries the main meaning while describing the process, and points at modal, phasic, specific and other characteristics of the activity or process. It is crucial for the student to be aware that any particular verb of motion while combining with different nouns of the same semantic group will express exactly the same activity's characteristics. Only the choice of noun changes the meaning of the word combination:

$\checkmark$ В эфир не вышли запланированные сюжеты-The planned reports didn't go on the air;

$\checkmark$ Эта книга не так давно вышла в свет в специализированном издательстве-Specialized publishing house published this book recently.

\section{The Phraseological Resources of Figurative Verbs of Motion}

Many papers about the endless resources of Russian verbs of motion have been written by linguists and writers. A. Usov (1999) considers verbs to be "one of the most lively part of the Russian speech". In his opinion, the "verb contains arterial blood of the Russian language". I. B. Golub (1977) in his book "Practical Stylistic of the Modern Russian Language" writes the "verb with all the richness of its semantic, with all its characteristics for grammatical forms meanings and options of its syntactic links is being an inexhaustible source of expression" (translation of the English in this quote should be checked. There are some errors here). This quotation is a perfect introduction for further analysis of the role of verbs in phraseologycal and idiomatic expressions.

The main role of motion verbs is to express narrative dynamic. Nevertheless, it is worth pointing out that these verbs are irreplaceable while creating art trails and, first of all, personification - a trope or figure of speech in which an inanimate object or abstraction is given human qualities or abilities:

"I love a storm in the beginning of May/When the first thunder of spring/As if frisking about and playing Crashes in the blue sky"

From "Spring Thunderstorm" Tiutchev (1986).

Allegorical expressions fill Russian speech, being used so frequently that it is difficult to manage conversation without them. Thus, it is easy to overlook their metaphorical nature. Verbs of motion used figuratively not only contribute to the success of poets and other writers but also contribute to our daily conversation. We often use these words in our daily life to make our speech more expressive and to show our emotions in a more detailed way. Thus, these verbs are integral to various idiomatic expressions, which are so popular, that they are required knowledge for both native speakers and foreign students who would like to learn Russian.

In Table 1, there is a quick review of the expressions or idioms which are recommended learning for foreign students since they are quite popular in Russian speech:

\section{The Stylistic Usage of Idiomatic Expressions with Figurative Verbs of Motion}

"Phraseologies or winged words are able to strengthen a speech and make it more convincing, colorful and picturesque." (Ashukin, 1960) The expression "winged words" is derived

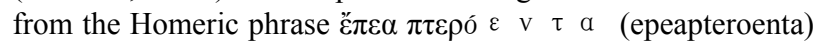
and now itself an example of "winged words". In the Iliad and the Odyssey, Homer (Mangel, 2009) uses the phrase "है $\pi \varepsilon \alpha$ $\pi \tau \varepsilon \rho \varepsilon_{\varepsilon v \tau \alpha} \pi \rho \circ \sigma \eta v \delta \alpha$ "-literally translated as "he/she spoke forth winged words".

Within poems, narratives, stories and other literary works, idioms are best grasped through literature. Thus, foreign students can become more familiar with figurative verbs of motion through the works of classical Russian writers. Poets and other writers often use these verbs to reveal the character of the protagonist or to make the author's language livelier.

The wide range of the idiomatic or figurative usage of verbs of motion can be seen in Tolstoy's (2010) "Candle" represented in Table 2.

The ways and methods of usage and formation of phraseological units in fiction are quite various. The examples discussed above show that the expressive possibilities might be interpreted differently depending on text structure, thematic aim and, finally, the writer's literary purposes. 
Table 1.

Expression and idioms with Russian verbs of motion in a figurative meaning and their meanings in English.

\begin{tabular}{|c|c|c|}
\hline \multirow{3}{*}{ No } & \multicolumn{2}{|c|}{ Idioms with Russian verbs of motion in a figurative meaning } \\
\hline & Russian & English \\
\hline & \multicolumn{2}{|c|}{ Идти-ходить (to go) } \\
\hline 1 & Время идёт быстро & Time flies \\
\hline 2 & $\begin{array}{c}\text { Идут экзамены } \\
\text { (/переговоры) }\end{array}$ & Exams/Negotiations are being held \\
\hline 3 & О чём идёт речь? & $\begin{array}{c}\text { What is the conversation about/what } \\
\text { are you talking about? }\end{array}$ \\
\hline 4 & $\begin{array}{c}\text { Идти на уступки (на риск, } \\
\text { на всё) }\end{array}$ & $\begin{array}{c}\text { To make concessions (to take a risk, } \\
\text { to be willing to do anything for a } \\
\text { goal) }\end{array}$ \\
\hline 5 & Это ещё куда не шло & That's not so bad! \\
\hline 6 & Дальше идти (ехать) некуда & $\begin{array}{l}\text { There's nothing that can be done/it } \\
\text { can't get worse (than this) }\end{array}$ \\
\hline 7 & Не идёт на ум & It doesn't come to mind. \\
\hline 8 & Ходить вокруг да около & To beat around the bush \\
\hline \multicolumn{3}{|c|}{ Плыть-плавать (to swim) } \\
\hline 9 & Плыть по течению & To go with the flow \\
\hline 10 & Плыть против течения & To go against the flow \\
\hline \multicolumn{3}{|c|}{ Лезть-лазить (to climb) } \\
\hline 11 & Лезть в воду (в драку) & $\begin{array}{c}\text { To climb into the water/get into a } \\
\text { fight }\end{array}$ \\
\hline 12 & Лезть не в своё дело & To butt into someone else's business \\
\hline 13 & $\begin{array}{c}\text { От боли (от злости) лезть на } \\
\text { стенку }\end{array}$ & To climb the walls from pain (anger) \\
\hline 14 & Лезть в карман & $\begin{array}{l}\text { To put a hand into someone's pocket, } \\
\text { for some reason. (i.e. to pick pocket) }\end{array}$ \\
\hline \multicolumn{3}{|c|}{ Нести-носить (to carry) } \\
\hline 15 & Нести наказание (расходы) & $\begin{array}{c}\text { To bear/suffer punishment (expenses, } \\
\text { expenditures) }\end{array}$ \\
\hline 16 & Нести ответственность & To carry/bear responsibility \\
\hline 17 & Нести вздор & To say absurd things \\
\hline 18 & От него несёт табаком & He smells of Tobacco \\
\hline 19 & Носить на руках & To carry in one's arms \\
\hline 20 & Носить фамилию мужа & To go by your husband's last name \\
\hline 21 & Носить кольцо на руке & To wear a ring on your hand \\
\hline \multicolumn{3}{|c|}{ Вести-водить (to lead) } \\
\hline 22 & Вести кружок & To lead a club \\
\hline 23 & Вести борьбу & To lead/conduct a struggle/fight \\
\hline 24 & Вести наблюдение & To observe \\
\hline 25 & Вести переговоры & To conduct negotiations \\
\hline 26 & Вести торговлю & To conduct trade \\
\hline 27 & Вести переписку & $\begin{array}{c}\text { To carry on correspondence (with } \\
\text { someone) }\end{array}$ \\
\hline 28 & Вести себя & To behave yourself \\
\hline 29 & Вести учёт & To take inventory \\
\hline 30 & Вести хозяйство & $\begin{array}{l}\text { To take care of the home, domestic } \\
\text { matters }\end{array}$ \\
\hline 31 & Вести праздную жизнь & To lead an empty life \\
\hline 32 & Водить за нос & To lead someone by the nose \\
\hline
\end{tabular}

Table 2.

Idiomatic usage of verbs of motion in a figurative meaning by Leo Tolstoy.

\begin{tabular}{|c|c|c|}
\hline \multirow{2}{*}{ No } & \multicolumn{2}{|c|}{$\begin{array}{l}\text { Idiomatic usage of verbs of motion in a figurative meaning by } \\
\text { Leo Tolstoy }\end{array}$} \\
\hline & Russian & English \\
\hline 1 & $\begin{array}{c}\text { Завел кирпичный завод, } \\
\text { всех- и баб и мужиков- } \\
\text { поморил на работе, а } \\
\text { кирпич продавал. }\end{array}$ & $\begin{array}{l}\text { He established a brick-yard, in which } \\
\text { he forced both men and women to do } \\
\text { excessive labour, and was selling the } \\
\text { bricks for his own profit. }\end{array}$ \\
\hline 2 & $\begin{array}{c}\text { Ходили мужики к } \\
\text { помещику в Москву } \\
\text { жаловаться, да не вышло их } \\
\text { дело. }\end{array}$ & $\begin{array}{l}\text { The serfs went to Moscow to } \\
\text { complain of their treatment to their } \\
\text { landowner, but it did not work out. }\end{array}$ \\
\hline 3 & $\begin{array}{c}\text { Нашлись из мужиков } \\
\text { неверные люди: стали } \\
\text { приказчику на своего брата } \\
\text { доносить и друг дружку } \\
\text { подводить. }\end{array}$ & $\begin{array}{l}\text { There were treacherous people among } \\
\text { the serfs who would denounce each } \\
\text { other. }\end{array}$ \\
\hline 4 & $\begin{array}{l}\text { А как налетел, все по } \\
\text { крапиве. }\end{array}$ & $\begin{array}{l}\text { No sooner did it appear than everyone } \\
\text { sneaked off in the nettles. }\end{array}$ \\
\hline 5 & $\begin{array}{c}\text { Смирный был мужик Петр } \\
\text { Михеев и не шел в совет с } \\
\text { мужиками. }\end{array}$ & $\begin{array}{l}\text { Peter Mikheev was a humble serf and } \\
\text { disagreed with the other serfs. }\end{array}$ \\
\hline 6 & $\begin{array}{c}\text { Ты станешь зло изводить, а } \\
\text { оно в тебя перейдет. }\end{array}$ & $\begin{array}{l}\text { If you start getting rid of evil by } \\
\text { killing, it will transfer into you. }\end{array}$ \\
\hline 7 & $\begin{array}{l}\text { Пошла кухарка, поднесла } \\
\text { старосте. }\end{array}$ & $\begin{array}{l}\text { The cook approached the village elder } \\
\text { and treated him with a glass of vodka. }\end{array}$ \\
\hline 8 & Видно, руки не доходят? & Evidently, he didn't get round to it. \\
\hline 9 & Дошло теперь и до меня! & It's my turn now! \\
\hline
\end{tabular}

\section{Conclusion}

The paper claims that the verb is the most important part of speech in the Russian language. There are a vast number of verbs in Russian, and it is important that English-speaking students learn the idioms of the Russian verbal system. Once the basic principles and rules are memorized and patterns are established, the student will be able to not only understand the meaning of idiomatic expressions using these verbs, but to use them in the right place and at the right time. Russian verbs of motion do not fit the stereotype of verbs used to describe only means of transportation or manner of movement. They are useful for describing a variety of situations-when you are lucky (“ему везёт"), conduct negotiations (“вести переговоры”) or even go against the flow (“плыть против течения"). Once students have familiarized themselves with the literal meaning of the verbs of motion, they will have an idea how to use them figuratively.

\section{REFERENCES}

Ashukin, A. S. (1960). Krilatie slova (p. 24). Moscow: Gosudarstvennoe Izdatel'stvo Hudojestvennoj Literatury.

Franke, J. E. (2005). The big silver book of Russian verbs (p. 28). New York: McGraw-Hill eBooks.

Golub, I. B. (1977). Prakticheskaya stilistika sovremennogo Russkogo yazika (p. 305). Moscow: Rolf, IRISS-Press.

Kalinovskaya, E., \& Tkachenko, N. (1972). Word combinations with prefixed and non-prefixed verbs like "to go" (p. 172). Moscow: Izdatel'stvo Sovremennoe Obrazovanie..

Mangel, A. (2009) Homer's the Iliad \& the Odyssey (p. 252). Moscow: AST.

Snejko, K. M. (2008). Verbs of motion “идти-ходить” (to go), “examb- 


\section{SKRIPNIKOVA}

ездить" (to go) and their equivalents in English language. Saint-Petersburg: SPGUTD

Tiutchev, F. I. (1986). Stihotvoreniya. Moscow: Sovetskaya Rossiya.
Tolstoy, L. (2010). Rasskazi (p. 57). Moscow: Rosman-Press.

Usov, A. K. (1999). Expressive options of Russian verbs (p. 53). Moscow: Eksmo. 